\title{
Digital Divide Measurement in Lembata Regency Using SIBIS
}

\author{
Cecilia Dai Payon Binti Gabriel ${ }^{1, *}$, Djoko Budiyanto Setyohadi ${ }^{2}$, Suyoto $^{2}$ \\ ${ }^{1}$ Informatics Engineering, STIMIKOM Stella Maris Sumba,Sumba Barat Daya NTT Indonesia, 85274 \\ ${ }^{2}$ Master Program of Informatics Engineering, Universitas Atma Jaya Yogyakarta, Yogyakarta Indonesia, 55281
}

\begin{abstract}
Along with technological development in Indonesia, digital divide occurs in various regions, which were behind in terms of information on how to use, access and utilize ICT in collecting information from internet. One of the regions is Lembata Regency in East Nusa Tenggara, where digital divide among the people should be measured. The purpose of this study was to determine the level of digital divide among the people of Lembata Regency. To determine the level of digital divide, we used SIBIS GPS (General Population Survey) method, which consisted of several indicators or aspect, i.e. internet usage behavior, internet utilization, and e-government. We also performed two tests, i.e. validity test and reliability test to obtain value of index of digital divide measurement among the people of Lembata Regency. The results of validity test which is processed using SPSS program are categorized valid for each variable indicator and the reliability test results show reliable status. According to the test results on digital discrepancy in Lembata people, the internet usage attitude ind icator is categorized low which is $63.1 \%$, the internet usage function indicator is categorized low which is $64 \%$, and the digital discrepancy of e-government ind icator is categorized medium which is $40.4 \%$. Therefore, the result of this study because consideration for the government of Lembata Regency in improving ICT services in e-government and in distributing ICT access and ability equally to the people.
\end{abstract}

\section{Introduction}

Technological development greatly influences people's lives. This is due to a divide in obtaining information and accessing information via internet in the society. Digital divide is an individual or group's ability in using ICT by accessing and utilizing it [1]. Digital divide is defined as those who access information technology and those who can't access it in collecting information via internet and unable to use it [2]. Digital divide is a gap of internet access and usage, which is separated by social economic status, gender, lifestyle, ethnicity, and geographic location, which illustrates a divide between communities and individuals who have resources to participate in the information era and those who don't. This digital divide really happens across the globe [3]. Digital divide is a divide between individuals, households, businesses and geographic areas at different social economic levels, opportunity to access ICT and internet usage for various activities [4].

Lembata is one region of East Nusa Tenggara Province, which consists of nine sub-districts. The vision of Lembata region is that "the realization of Lembata Region which is independent and productive based on its potency in layout" [5]. In order to fulfill that vision, knowledge in science and technology is needed. However, not all of its areas have the proper access to and skill in information and communication technology and thus there is digital discrepancy between them.

The purpose of this paper was to discuss digital divide in the government of Lembata Regency. ICT utilization in governance is called e-government. Egovernment aims to help efficiently run a government system and use ICT for the people in Lembata Regency. However, not everyone in Lembata Regency has access and ability in using and utilizing ICT. It's due to difference in access and ability in utilizing ICT, creating digital divide among the people of Lembata Regency.

Digital divide among the people in Lembata Regency should be measured to contribute to understanding on digital divide along with various literatures and studies by the government of Lembata Regency. The contribution was used as consideration in creating policy strategy in public service and to be used by the government to spread ICT access and ability equally to the people in Lembata Regency. Digital divide is measured by SIBIS (Statistical Indicators Benchmarking the Information Society) method. SIBIS consists of several indicators, i.e. internet usage behavior, internet utilization and e-government.

The result of this study became a reference for the government of Lembata Regency in providing ICT services for the people by providing integrated services, training for internet access and information collection. 
Therefore, digital divide should be measured by adjusting with local condition in Lembata Regency.

\section{Material and Method}

\subsection{Digital Divide}

The definition of digital divide is a divide between those who own computers and can access internet and those who don't own computer and can't access information via internet [2]. Moreover, there is digital divide between the rich who can easily get information from internet and the poor who can't get information or access information via internet. [5]. Digital divide is also defined as a divide between individuals, households, businesses, geographies, economic levels in opportunity to get and access information by using internet. [6]. Digital divide is also called a divide in accessing computer and internet between men and women, among people with different social economic statuses, ages and demographics. [7]. Furthermore, digital divide isn't only about a divide of access to ICT but also a divide in ability in using ICT. Whether accessing internet or using internet, it can't be removed from individual's ability and skill [8].

Digital divide according to Presidential Instruction number 3 of 2003 on National Policy and Strategy for EGovernment Development is defined as isolation from global development due to inability to utilize information. It's also mentioned that inability to adjust with global trend will lead Indonesia into a great digital divide, which is isolation from global development due to inability to utilize information [9]. E-Government itself is utilization of communication and information technology in governance process (e-government) to improve efficiency, effectiveness, transparence and accountability of governance. Article 5 of Presidential Instruction No.3 of 2003 on National Policy and Strategy for E-Government Development states that "Therefore, the government must immediately perform transformation process toward e-government. Through the transformation process, the government can optimize utilization of information technology development to eliminate dividers between bureaucratic organizations, and form management system network and work process which enable government agencies to work in integration to simplify access to all information and public services which must be provided by the government.

Therefore, all national institutions, the society, business world, and other stakeholders can use government information and services optimally anytime. It requires strong leadership in each institution or government unit so that the transformation process toward e-government can be performed optimally."

Studies on e-government to measure digital divide have been performed by other researchers. According to Chalita Srinuan, a measurement was performed among community groups and countries in Thailand using econometric method. The study showed that demand factors commonly found in United States and European Union are also found in Thailand. Digital divide in
Thailand was created by interactions between factors of demand and offer. They are both required to promote benefits in adopting internet and to bridge digital divide [10]. Beside using econometric method, digital divide can be measured by a method used in European society, i.e. SIBIS (Statistic Indicators Benchmarking The Information Society). One of the studies using SIBIS model is the study by Alivia Yulfitri. The object of the study is the world of education by a case study in Senior High School Kotamadya in Bandung.

This study was performed on teachers in the school. The result of the research shows relation between availability of ICT access facility and mastery of ICT, availability of ICT access facility and level of ICT mastery, and availability of ICT access facility and utilization of ICT [11]. SIBIS method was also used in the study by Syarif Hidayatullah in South Tapanuli Regency in Department of Plantation and Animal Husbandry. The study was performed using SIBIS GPS (General Population Survey) method. The research result shows that the level of ICT access divide I high and the ICT skill divide is medium, while digital divide by age, income, education has quite great influence on digital divide among human resources and gender doesn't significantly influence the level of digital divide [12]. A study on digital divide in local government was performed by Ike Pertiwi Windasari and Kridanto Surendro. The study was performed in the local government of Semarang for equalizing ICT skill of human resources and to close the gap in competence in developing e-government system by training employees and recruiting new employees who can use SIBIS GPS and DIDIX instruments. The result of this study shows that the government of Semarang has obstacles in ICT adoption due to lack of training for the employees, low awareness of the employees to join training, and a lack of training by organization [13]. A study on digital divide in Pekalongan was performed by Dyah Listianing Tyas. The research result is used by the government of Pekalongan in spreading ICT access and skill by providing infrastructures and training programs to develop human resources [14].

Digital divide is caused by factors of internet access and usage, which are separated by social economic status, gender, ethnicity, lifestyle and geographic location [15]. Digital divide was focused on the following:

a. Infrastructure

Defining difference between individual who owns

ICT infrastructure and internet connection and individual who doesn't own ICT infrastructure and internet connection.

b. ICT skill achievement

Defining individual who tries to have required ICT skill and individual who doesn't put effort in having the required ICT skill.

c. Resources utilization

Defining individual's limitation in using resources available in internet media. Moreover, it defines individual who is unable to access information, knowledge and the latest information. 


\subsection{SIBIS}

To measure the level of digital divide, SIBIS (Statistical Indicators Benchmarking the Information Society) method was used. It's a European commissioned project to analyze and compare various indicators of divide. The indicators used in measuring digital divide among the people of Lembata Regency are:

a. Internet usage behavior

b. Internet utilization

c. Demography

d. E-government.

The SIBIS method used in measuring digital divide in the people of Lembata Regency has the following strengths and weaknesses:

a. Strength

i. Readiness of internet

ii. Digital divide

iii. Security of information

iv. Immediate response to access

v. Digital literacy, leaning and training

vi. E-commerce, e-work, e-science, egovernment, e-health

b. Weakness

Indicator of digital divide doesn't properly emphasize social and economic gaps (Source: [16])

In SIBIS, digital divide of internet usage behavior includes computer usage, internet usage, internet access, digital divide index, internet usage utilization divide, intensity of internet usage, termination of internet usage, email usage and e-government divide, which includes avalaibility of e-government, e-government usage, and egovernment assessment [17].

\subsection{Research Method}

The research is conducted in several steps simultaneously which starts from collecting until measuring data to process and to investigate the data. The data is divided into two which are primary data and secondary data. The primary data are gained through spreading queries while the secondary data are obtained through desk research method, any support is taken from books, journals and papers. The author uses Business Information System Method to investigate digital discrepancy in governmental level of Lembata Region when they plan the community service policy strategies regarding information and communication technology. Figure 1 is the flow diagram to measure digital discrepancy of Lembata people.

The research method applied in this study is started with literature study and problem formulation. Literature study and problem formulation are meant to gain knowledge in terms of data collecting process of this research. The next step is determining which method is appropriate to carry this research. If the method is decided, preparing the queries can be conducted for the queries is the base of this study. After that, the author uses the queries to collect data and the required information regarding digital discrepancy. Then, the collected data will be investigated using SPSS version 20 software. These steps end with query data processing and making conclusions from the results.

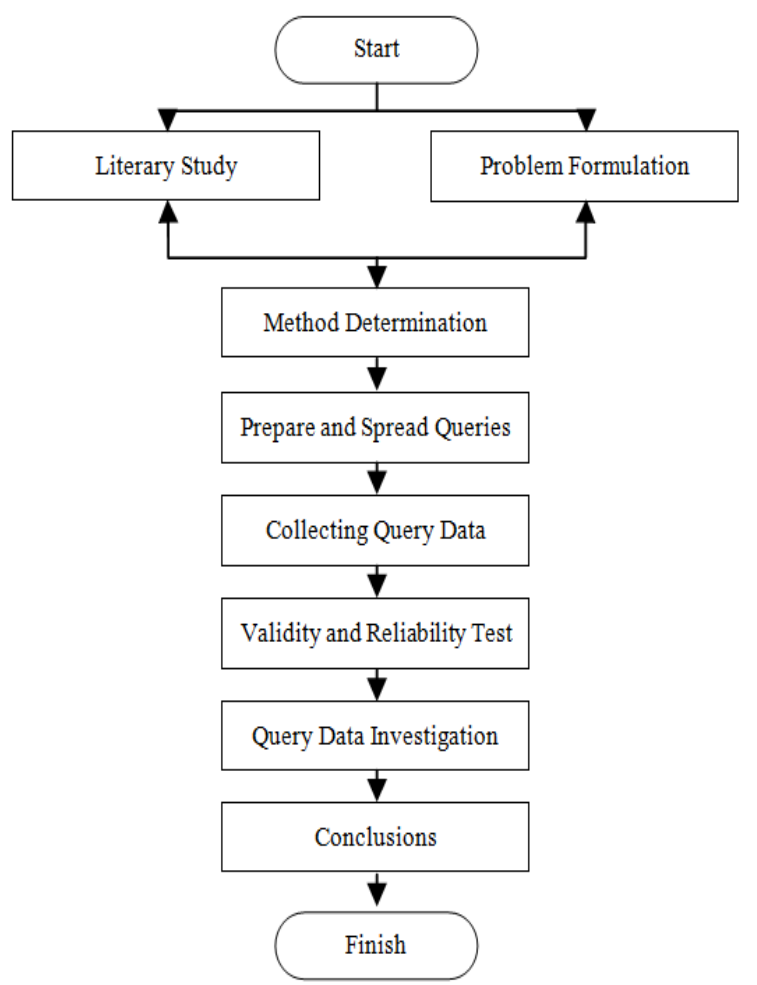

Fig. 1. Flow Diagram

In the present study, the researchers collected data through questionnaires distributed to the people of Lembata Regency. The population of Lembata Regency was 132,171 . The data was collected in 2016 [18]. The detail of the population of each sub-district is below:

Table 1. The detail of the population of each sub-district

\begin{tabular}{llc}
\hline No & \multicolumn{1}{c}{ Sub-district } & Population (people) \\
\hline 1 & Nagawutung Sub-district & 9368 \\
2 & Wulandoni Sub-district & 8503 \\
3 & Atadei Sub-district & 7568 \\
4 & Ile Ape Sub-district & 12158 \\
5 & East Ile Ape Sub-district & 5119 \\
6 & Lebatukan Sub-district & 45585 \\
7 & Omesuri Sub-district & 15548 \\
8 & Buyasuri Sub-district & 19523 \\
\hline
\end{tabular}

From the population of Lembata Regency, samples were collected using Slovin's formula to determine the number of sample [19]. The total sample was 133 respondents. The Slovin's formula is:

$$
\mathrm{n}=\frac{\mathrm{N}}{1+\mathrm{Ne}^{2}}
$$

Note:

n : total sample

$\mathrm{N}$ : population size

e : percent of allowance of inaccuracy due to error 
Furthermore, the sampling technique in determining population was proportionate stratified random sampling method [20]. The sample result was processed and tested by validity and reliability tests.

\subsubsection{Validity Test}

Validity test is used to the validity of questionnaire. If a questionnaire is valid, it can reveal what is measured by the questionnaire. Validity test is a measurement which showed how variable to be measured matches variable to be studied by researcher [21]. In the present study, validity test was validity of each question and validity index was found using product moment correlation formula :

$$
r=\frac{N \sum X Y-\left(\sum X \sum Y\right)}{\left.\sqrt{\left[N \sum X^{2}\right.}-\left(\sum X\right)^{2}\right]\left[N \sum Y^{2}-\left(\sum Y\right)^{2}\right]}
$$

$$
\begin{array}{ll}
\text { Note : } & \\
\mathrm{r}= & \text { Correlation rate } \\
\mathrm{N}= & \text { Number of respondent } \\
\mathrm{X}= & \text { Score or question or statement } \\
\mathrm{Y}= & \text { Total Score of sub variable }
\end{array}
$$

\subsubsection{Reliability Test}

Reliability test is an index showing how far a measurement instrument can be trusted or relied on. In other words, the instrument has consistent result despite being used repeatedly at different times. Reliability test is performed by alpha cronbach technique. An instrument is reliable if it has reliability of alpha amounting to 0,6 or more. The technique uses the following formula:

$$
\alpha=\left[\frac{\mathrm{K}}{\mathrm{K}-1}\right]\left[1 \frac{\sum \sigma_{1}^{2}}{\sum \sigma_{\mathrm{t}}^{2}}\right]
$$

Note :

$\alpha \quad$ : Reliability value

$\mathrm{k} \quad$ : Total question or statement item

$\sum \sigma_{1}^{2}:$ Variance value of each item

$\sum \sigma_{\mathrm{t}}^{2}$ : Total value

This test processes and analyzes in descriptive statistic to determine the category of the level of digital divide among the people of Lembata Regency. The categories in the assessment of the digital divide were:
a. Index $<20.00 \%$
: very high
b. $20.00 \% \leq$ index $<40.00 \%$ : high
c. $40.00 \% \leq$ index $<60.00 \%$ : medium
d. $60.00 \% \leq$ index $80.00 \%$ : low
e. Index $\geq 80.00 \% \quad$ : very low

\section{Results and Discussion}

In the discussion, validity test and reliability tests were performed using an application or program called SPSS. Validity test was performed using correlation, where correlation value (pearson correlation) must be positive to mean that the instrument is valid and if it's negative then the instrument is invalid. Meanwhile, reliability test was performed by alpha-cronbach test, in which if coefficient alpha value is bigger than 0,6 , then it's reliable.

The research method applied in this study is started with literature study and problem formulation. Literature study and problem formulation are meant to gain knowledge in terms of data collecting process of this research. The next step is determining which method is appropriate to carry this research. If the method is decided, preparing the queries can be conducted for the queries is the base of this study. After that, the author uses the queries to collect data and the required information regarding digital discrepancy. Then, the collected data will be investigated using SPSS version 20 software. These steps end with query data processing and making conclusions from the results.

The following are the instruments which their validity and reliability are tested to determine whether or not they meet the analysis requirements. Validity test is used to examine whether the instruments are valid and can be used to measure. Reliable research instruments are the instruments used to examine the same research objects several times and produce same results.

\subsection{Validity Test}

The validity test is carried using correlation in SPSS version 20 software. Table 2 presents the validity test result on variable $\mathrm{X}_{1}$ for internet usage attitude:

Table 2. Validity test result on variable $X_{1}$ for internet usage

\begin{tabular}{llll}
\hline Variable & r Count & r Table & Status \\
\hline X1,1 & 0,36 & 0,1703 & Valid \\
X1,2 & 0,226 & 0,1703 & Valid \\
X1,3 & 0,282 & 0,1703 & Valid \\
X1,4 & 0,394 & 0,1703 & Valid \\
X1,5 & 0,308 & 0,1703 & Valid \\
X1,6 & 0,241 & 0,1703 & Valid \\
X1,7 & 0,344 & 0,1703 & Valid \\
X1,8 & 0,422 & 0,1703 & Valid \\
X1,9 & 0,341 & 0,1703 & Valid \\
X1,10 & 0,313 & 0,1703 & Valid \\
X1,11 & 0,305 & 0,1703 & Valid \\
X1,12 & 0.405 & 0,1703 & Valid \\
X1,13 & 0,371 & 0,1703 & Valid \\
X1,14 & 0,368 & 0,1703 & Valid \\
X1,15 & 0,232 & 0,1703 & Valid \\
X1,16 & 0,175 & 0,1703 & Valid \\
X1,17 & 0,222 & 0,1703 & Valid \\
X1,18 & 0,281 & 0,1703 & Valid \\
X1,19 & 0,245 & 0,1703 & Valid \\
\hline
\end{tabular}

If $r$-count $>r$-table, thus it is categorized as valid and if $\mathrm{r}$-count $<\mathrm{r}$-table, thus it is categorized as invalid. $\mathrm{r}$ Count value is gained from SPSS Reliability analysis in corrected item total correlation column. With 200 correspondents and 2 independents in which significance rate is at 0.05 , thus r-table is acquired at 0.1703 . The following is $\mathrm{X}_{2}$ or internet usage function validity test (Table 3 ) result: 
Table 3. Internet usage function validity test result

\begin{tabular}{cccc}
\hline Variable & r Count & r Table & Status \\
\hline X2,1 & 0,426 & 0,1703 & Valid \\
X2,2 & 0,345 & 0,1703 & Valid \\
X2,3 & 0,338 & 0,1703 & Valid \\
X2,4 & 0,284 & 0,1703 & Valid \\
X2,5 & 0,495 & 0,1703 & Valid \\
X2,6 & 0,487 & 0,1703 & Valid \\
X2,7 & 0,267 & 0,1703 & Valid \\
X2,8 & 0,392 & 0,1703 & Valid \\
X2,9 & 0,345 & 0,1703 & Valid \\
X2,10 & 0,255 & 0,1703 & Valid \\
X2,11 & 0,313 & 0,1703 & Valid \\
X2,12 & 0,416 & 0,1703 & Valid \\
X2,13 & 0,288 & 0,1703 & Valid \\
X2,14 & 0,298 & 0,1703 & Valid \\
X2,15 & 0,439 & 0,1703 & Valid \\
X2,16 & 0,449 & 0,1703 & Valid \\
X2,17 & 0,345 & 0,1703 & Valid \\
X2,18 & 0,377 & 0,1703 & Valid \\
X2,19 & 0,272 & 0,1703 & Valid \\
X2,20 & 0,323 & 0,1703 & Valid \\
X2,21 & 0,343 & 0,1703 & Valid \\
X2,22 & 0,358 & 0,1703 & Valid \\
X2,23 & 0,315 & 0,1703 & Valid \\
X2,24 & 0,285 & 0,1703 & Valid \\
\hline
\end{tabular}

The result of $\mathrm{Y}$ or e-government variable validity test is presented in table 4 :

Table 4. The result of $\mathrm{Y}$ or e-government variable validity test

\begin{tabular}{|c|c|c|c|}
\hline Variable & r Count & r Table & Status \\
\hline $\mathrm{Y}, 1$ & 0,233 & 0,1703 & Valid \\
\hline $\mathrm{Y}, 2$ & 0,416 & 0,1703 & Valid \\
\hline $\mathrm{Y}, 3$ & 0,372 & 0,1703 & Valid \\
\hline$Y, 4$ & 0,391 & 0,1703 & Valid \\
\hline $\mathrm{Y}, 5$ & 0,178 & 0,1703 & Valid \\
\hline Y,6 & 0,342 & 0,1703 & Valid \\
\hline$Y, 7$ & 0,228 & 0,1703 & Valid \\
\hline $\mathrm{Y}, 8$ & 0,431 & 0,1703 & Valid \\
\hline $\mathrm{Y}, 9$ & 0,402 & 0,1703 & Valid \\
\hline$Y, 10$ & 0,339 & 0,1703 & Valid \\
\hline $\mathrm{Y}, 11$ & 0,319 & 0,1703 & Valid \\
\hline $\mathrm{Y}, 12$ & 0,373 & 0,1703 & Valid \\
\hline$Y, 13$ & 0,191 & 0,1703 & Valid \\
\hline$Y, 14$ & 0,219 & 0,1703 & Valid \\
\hline$Y, 15$ & 0,474 & 0,1703 & Valid \\
\hline$Y, 16$ & 0,523 & 0,1703 & Valid \\
\hline $\mathrm{Y}, 17$ & 0,502 & 0,1703 & Valid \\
\hline $\mathrm{Y}, 18$ & 0,452 & 0,1703 & Valid \\
\hline$Y, 19$ & 0,446 & 0,1703 & Valid \\
\hline$Y, 20$ & 0,434 & 0,1703 & Valid \\
\hline$Y, 21$ & 0,399 & 0,1703 & Valid \\
\hline $\mathrm{Y}, 22$ & 0,553 & 0,1703 & Valid \\
\hline$Y, 23$ & 0,509 & 0,1703 & Valid \\
\hline$Y, 24$ & 0,403 & 0,1703 & Valid \\
\hline
\end{tabular}

According to the table, it is found that all tested indicators show r-count $>$ table value which is 0.1703 . Therefore, it is concluded that all research variable indicators are valid.

\subsection{Reliability Test}

To examine the reliability of each research variable, it uses Cronbach-Alpha test. The queries are declared reliable if they have alpha coefficient value bigger than 0.6 . Here are the results:

Table 5. To examine the reliability

\begin{tabular}{lcc}
\hline \multicolumn{1}{c}{ Variable } & Alpha Value & Status \\
\hline Internet usage behavior (X1) & 0,735 & Reliable \\
Internet usage utilization (X2) & 0,814 & Reliable \\
E-government (Y) & 0,833 & Reliable \\
\hline
\end{tabular}

Based on the table above, it is concluded that internet usage attitude variable (X1), internet usage function (X2) and e-government have reliable statuses because their alpha coefficient values are $>0.06$.

Using SIBIS GPS method which consists of several indicators discussed above, a measurement should be performed on the people of Lembata Regency. The table of digital divide by indicator is shown below:

a. The level of digital divide by internet usage behavior

Table 6. The level of digital divide by internet usage behavior

\begin{tabular}{|c|c|c|c|}
\hline Indicator & & Sub-indicator & $\begin{array}{c}\text { Percentage } \\
(\%)\end{array}$ \\
\hline \multirow{4}{*}{$\begin{array}{l}\text { Internet } \\
\text { behavior }\end{array}$} & \multirow{3}{*}{ usage } & In work & 65,2 \\
\hline & & Personal activity & 63,7 \\
\hline & & Ease of access & 60,4 \\
\hline & \multicolumn{2}{|c|}{ Total average } & 63,1 \\
\hline
\end{tabular}

The test result on the digital divide among the people of Lembata Regency by internet usage behavior in SIBIS method in terms of sub-indicator internet usage in work of 133 respondents was $65.2 \%$. It showed that the level of internet usage in work is low. Sub-indicator internet usage in personal activity among the people of Lembata Regency was $63.7 \%$. It showed a divide in internet usage in personal activities, such as finishing tasks from teacher or lecturer or work. Sub-indicator ease in accessing internet among the people of Lembata Regency was $60.4 \%$. It showed that that the divide among the people in being facilitated to access information was low. Therefore, it is concluded that the digital divide among the people of Lembata Regency in terms of internet usage behavior was $63.1 \%$, showing low level of digital divide among the people of Lembata Regency.

b. The level of digital divide by internet usage utilization

The percentage of internet usage utilization in SIBIS method in terms of sub-indicator internet usage utilization to find information on internet of 133 respondents was $65.7 \%$. It showed that the people of Lembata Regency lacked knowledge on information through internet usage. Meanwhile, sub-indicator internet usage to collect information online was $64.2 \%$. It showed that the people of Lembata Regency didn't 
understand how to collect information online. Subindicator sending work data by email was $62,1 \%$. It showed that e-mail usage was low and not understood by the general public of Lembata Regency. It's concluded that the level of digital divide of indicator internet usage utilization was $64 \%$, and the three sub-indicators showed that the level of the divide among the people of Lembata Regency was low.

Table 7. The level of digital divide by internet usage utilization

\begin{tabular}{llc}
\hline \multicolumn{1}{c}{ Indicator } & \multicolumn{1}{c}{ Sub-indicator } & $\begin{array}{c}\text { Percentage } \\
\text { (\%) }\end{array}$ \\
\hline & $\begin{array}{l}\text { Finding information via } \\
\text { internet on daily basis }\end{array}$ & 65,7 \\
& $\begin{array}{l}\text { Using internet to get } \\
\text { information online }\end{array}$ & 64,2 \\
$\begin{array}{l}\text { Internet usage } \\
\text { utilization }\end{array}$ & $\begin{array}{l}\text { Sending work data via } \\
\text { e-mail }\end{array}$ & 62,1 \\
& Total average & 64 \\
\hline
\end{tabular}

c. The level of digital divide by e-government

Table 8. The level of digital divide by e-government

\begin{tabular}{clc}
\hline Indicator & \multicolumn{1}{c}{ Sub-indicator } & $\begin{array}{c}\text { Percentage } \\
\text { (\%) }\end{array}$ \\
\hline \multirow{5}{*}{ E-government } & Finding information & 40,3 \\
& via e-government & \\
& service & \\
& $\begin{array}{l}\text { Ease of e-government } \\
\text { service }\end{array}$ & 37,4 \\
& $\begin{array}{l}\text { Ease of access } \\
\text { Confidence } \quad \text { in } \\
\text { correctness of e- } \\
\text { government } \\
\text { information } \\
\text { Total Average }\end{array}$ & \\
\hline
\end{tabular}

The percentage of e-government behavior in SIBIS method in terms of sub-indicator search for information via e-government service of 133 respondents was $40.3 \%$. It showed that people were able to use the application prepared by the government of Lembata Regency with egovernment service well. Sub-indicator ease of egovernment service was $37.4 \%$. It showed that egovernment service was easier to understand and easy to access by the people in Lembata Regency. Sub-indicator ease of internet access was $42.5 \%$. Sub-indicator confidence in correctness of e-government information was $41.4 \%$. It showed that the people in Lembata Regency were able to look for the correctness of information via the service provided by the local government. So, it's concluded that the level of digital divide of indicator e-government from four subindicators was $40.4 \%$. It showed that the level of the divide for indicator e-government was medium.

The result above showed internet usage behavior, internet usage utilization and e-government according to
SIBIS GPS [17]. It's concluded the government of Lembata Regency must consider a lot of things in providing ICT in public services.

Moreover, the result above showed that the people in Lembata Regency lacked experience and understanding on internet usage and how to access internet properly. So, the government of Lembata Regency must provide socialization to people to improve knowledge on internet usage in getting information.

It's concluded that the level of digital divide among the people of Lembata Regency was at medium level. It's evident in low internet usage behavior, low internet usage utilization and medium e-government. So, the government of Lembata Regency should consider reducing digital divide in the society.

\section{Conclusion}

The analysis result showed that SIBIS method described digital divide values among the people of Lembata Regency. The digital divide in terms of internet usage behavior was low $(63.1 \%)$. Internet usage utilization low (64\%), and e-government medium $(40.4 \%)$

The analysis result can be used as consideration for the government of Lembata Regency to improve public ICT service related with digital divide and reduce digital divide in Lembata Regency.

\section{References}

1. S. Baase, Issues for Computing Technology 4th New Jersey : Prentice Hall PTR, (2012).

2. E. Hargittai, Sociology Departemen Princeton University, pp. 1-22, (2003).

3. W. C. a. B. Wellman, Charting and Bridging Digital Divides: Comparing Socio-economic. Gender, Life Stage, and Rural-Urban Internet Access and use in Eight Countries, (2003).

4. OECD, Understanding the Digital Divide, Paris Cedex 16, France: OECD, (2001).

5. Administrator, "Situs Resmi BPS Kabupaten Lembata," 2016. [Online]. Available: https://lembatakab.bps.go.id/. [Accessed 06 May 2016].

6. I. C. a. T. T. Kidd, Digital Divide Implications and Trends, Texas: IGI Global, pp. 130-132, (2008)

7. J. a. D. Preeti Dubey, BIJIT-BVICAM's Internasional Journal of Information Techonology, pp. 341-346, July-December (2011).

8. S. J. Min, Journal of Information Techonology and Politics, pp. 1-15, (2010).

9. E. A.-S. a. R. Khasawneh, International Conference on Information Technology, vol. 6 th , pp. 1-8, 8 May (2013).

10. Inpres, Kebijakan dan Strategi Nasional, Jakarta, (2013). 
11. P. S. E. B. Chalita Srinuan, Telematics and Informatics, pp. 254-262, (2012).

12. A. Yulfitri, Konferensi dan Temu Nasional Teknologi Informasi dan Komunikasi untuk Indonesia, pp. 1-5, 21-23 Mei (2008).

13. S. Hidayatullah, Universitas Negeri Padang, Padang, (2013).

14. K. S. Ike Pertiwi Windasari, Jurnal Sistem Komputer, Vol.1, No.2, pp. 71-75, 2011.

15. A. B. A. J. S. Dyah Listianing Tyas, SENTIKA 2016, pp. 590-598, 18-19 Maret (2016).

16. C. a. B. W. Wenhong, AMD Global Consumer Advisory Board, (2003).

17. K. Barzilai-Nahon, Washington : The Information Society: An International Journal, (2006).
18. SIBIS, Information Society Technologies and European Commission, Germany, (2003).

19. Martono, Metode penelitian kualitatif, Bandung: Alfabeta, (2012).

20. Sugiyono, Metode Penelitian Bisnis, Bandung: Alfabeta., (2010).

21. D. R. C. a. P. S. Schindler, McGraw-Hill Internation Edition, (2006).

22. 2. Yulfitri.

23. SIBIS, Information Society Technologies, Germany, (2003).

24. B. N. K, The Information Society, (2006).

25. E. Hargittai, The Digital Divide and What To Do About It, San Diego, CA: Sociology Department, Princeton University and New Economy Handbook edited by Derek C. Jones, (2003). 